University of Nebraska - Lincoln

DigitalCommons@University of Nebraska - Lincoln

\title{
Winter use of a rock crevice by northern long-eared myotis (Myotis septentrionalis) in Nebraska
}

\author{
Jeremy A. White \\ University of Nebraska at Omaha, jeremywhite@unomaha.edu \\ Patricia Freeman \\ University of Nebraska-Lincoln, pfreeman1@unl.edu \\ Hans W. Otto \\ University of Arizona, hotto@email.arizona.edu \\ Cliff Lemen \\ University of Nebraska-Lincoln, clemen2@unl.edu
}

Follow this and additional works at: https://digitalcommons.unl.edu/natrespapers

Part of the Natural Resources and Conservation Commons, Natural Resources Management and Policy Commons, and the Other Environmental Sciences Commons

White, Jeremy A.; Freeman, Patricia; Otto, Hans W.; and Lemen, Cliff, "Winter use of a rock crevice by northern long-eared myotis (Myotis septentrionalis) in Nebraska" (2020). Papers in Natural Resources. 1074.

https://digitalcommons.unl.edu/natrespapers/1074

This Article is brought to you for free and open access by the Natural Resources, School of at DigitalCommons@University of Nebraska - Lincoln. It has been accepted for inclusion in Papers in Natural Resources by an authorized administrator of DigitalCommons@University of Nebraska - Lincoln. 


\title{
Western North American Naturalist
}

Volume 80

Number 1 - Issue in Progress

Article 14

$2-7-2020$

\section{Winter use of a rock crevice by northern long-eared myotis (Myotis septentrionalis) in Nebraska}

\author{
Jeremy A. White \\ Department of Biology, University of Nebraska at Omaha, Omaha, NE, jeremywhite@unomaha.edu \\ Patricia W. Freeman \\ School of Natural Resources and University of Nebraska State Museum, University of Nebraska-Lincoln, \\ Lincoln, NE, pfreeman1@unl.edu \\ Hans W. Otto \\ Department of Ecology and Evolutionary Biology, University of Arizona, Tucson, AZ, \\ hotto@email.arizona.edu \\ Cliff A. Lemen \\ Retired, clemen3210@gmail.com
}

Follow this and additional works at: https://scholarsarchive.byu.edu/wnan

\section{Recommended Citation \\ White, Jeremy A.; Freeman, Patricia W.; Otto, Hans W.; and Lemen, Cliff A. (2020) "Winter use of a rock crevice by northern long-eared myotis (Myotis septentrionalis) in Nebraska," Western North American Naturalist: Vol. 80 : No. 1 , Article 14. \\ Available at: https://scholarsarchive.byu.edu/wnan/vol80/iss1/14}

This Note is brought to you for free and open access by the Western North American Naturalist Publications at BYU ScholarsArchive. It has been accepted for inclusion in Western North American Naturalist by an authorized editor of BYU ScholarsArchive. For more information, please contact scholarsarchive@byu.edu, ellen_amatangelo@byu.edu. 


\title{
Winter use of a rock crevice by northern long-eared myotis (Myotis septentrionalis) in Nebraska
}

\author{
Jeremy A. White ${ }^{1, *}$, Patricia W. Freeman 2 , Hans W. Otto ${ }^{3}$, and Cliff A. Lemen ${ }^{4}$ \\ ${ }^{1}$ Department of Biology, University of Nebraska at Omaha, Omaha, NE 68182 \\ ${ }^{2}$ School of Natural Resources and University of Nebraska State Museum, University of Nebraska-Lincoln, Lincoln, NE 68583 \\ ${ }^{3}$ Department of Ecology and Evolutionary Biology, University of Arizona, Tuscon, AZ 85721 \\ 43210 Dudley Street, Lincoln, NE 68503
}

\begin{abstract}
AвSTRACT.-We used a combination of acoustic detectors, thermal imaging cameras, and mist netting to confirm the use of a rock crevice by northern long-eared myotis (Myotis septentrionalis) in winter in northeastern Nebraska. Bats roosted in a large crevice in a rock face along the Missouri River, and 5 individuals were captured emerging from the opening of the crevice in March 2017. Our study is the first to confirm the use of a rock-crevice hibernaculum by M. septentrionalis and adds to the growing literature on the winter use of rock crevices by hibernating bats in North America. As white-nose syndrome (WNS) continues to spread across North America and decimate populations of M. septentrionalis, more knowledge of hibernation requirements is necessary to develop an effective recovery plan and to monitor this threatened species.
\end{abstract}

Resumen.-A partir del uso combinado de detectores acústicos, cámaras termográficas y redes de niebla, confirmamos el uso de grietas en las rocas como refugio del murciélago Myotis septentrionalis, durante el período de invierno, al noreste de Nebraska. Observamos murciélagos en una gran grieta en una roca del río Missouri, de donde cinco ejemplares fueron captados saliendo de ella en marzo de 2017. Nuestro estudio es el primero en confirmar que el M. septentrionalis utiliza grietas en las rocas a modo de refugio, durante el invierno, esta información se suma a la creciente bibliografía que confirma el uso de grietas en la roca por los murciélagos que hibernan en América del Norte. A medida que el síndrome de la nariz blanca (WNS, por sus siglas en inglés) continúa propagándose por América del Norte y diezmando las poblaciones de M. septentrionalis, es necesario indagar sobre sus condiciones de hibernación para desarrollar un plan efectivo de restauración y monitorear a esta especie amenazada.

Researchers have speculated for decades that bats in temperate zones use rock crevices as hibernacula (Griffin 1945, Twente 1960), but verification of this behavior has been difficult (Bogan et al. 2003). However, recent studies have confirmed the use of rock crevices in autumn and winter by a variety of species in North America (Lausen and Barclay 2006, Neubaum et al. 2006, Perry et al. 2010, Barnhart and Gillam 2017, Johnson et al. 2017, Klüg-Baerwald et al. 2017, Moosman et al. 2017, Neubaum 2018). For example, big brown bats (Eptesicus fuscus) used rock crevices in autumn in Colorado (Neubaum et al. 2006) and Wyoming (Johnson et al. 2017), in winter in Alberta (Lausen and Barclay 2006, Klüg-Baerwald et al. 2017), and in winter in Virginia (Moosman et al. 2017). In addition, silver-haired bats (Lasionycteris noctivagans) occasionally used rock outcrops in winter in Arkansas (Perry et al. 2010). Among species of Myotis, western small-footed myotis (Myotis ciliolabrum) used rock crevices in autumn in North Dakota (Barnhart and Gillam 2017) and Wyoming (Johnson et al. 2017), eastern smallfooted myotis (Myotis leibii) roosted in crevices in winter in Virginia (Moosman et al. 2017), western long-eared myotis (Myotis evotis) used crevices in autumn in Wyoming (Johnson et al. 2017), and little brown myotis (Myotis lucifugus) used rock crevices in autumn in Wyoming (Johnson et al. 2017) and in winter in Colorado (Neubaum 2018). These observations on autumn and winter roosting behavior are important in light of the emergence and spread of the disease white-nose syndrome (WNS) caused by the fungus Psuedogymnoascus destructans $(P d)$, which has resulted in drastic population

*Corresponding author: jeremywhite@unomaha.edu 
declines of some species of hibernating bats in North America, including Perimyotis subflavus, M. lucifugus, and Myotis septentrionalis (Langwig et al. 2012, Frick et al. 2015, 2017). In addition to caves and mines, rock crevices and other alternative hibernacula will be important to identify and monitor as WNS continues to spread. Thus, it is critical to determine whether other species of bats in North America also hibernate in rock crevices.

The northern long-eared myotis (M. septentrionalis) has traditionally been thought to use caves or mines for hibernation (Caceras and Barclay 2000), but few individuals, relative to their abundance in summer, are typically found during surveys of these hibernacula (Griffin 1940, Caire et al. 1979, Whitaker and Rissler 1992). It is possible that M. septentrionalis occurs in larger numbers in caves and mines but that individuals are often missed during surveys because they prefer to use crevices within these hibernacula. Evidence supporting this idea includes observations of M. septentrionalis in crevices in a variety of caves and mines (Griffin 1940, Caire et al. 1979, Whitaker and Rissler 1992, J. White personal observations) and captures of individuals at entrances of caves and mines, when few were found within the hibernaculum (Caire et al. 1979, Whitaker and Rissler 1992, J. White personal observations). Another possibility is that some northern long-eared myotis use alternative hibernacula besides caves and mines. Indeed, M. septentrionalis has been found using a hydroelectric dam in Michigan (Kurta and Teramino 1994), a storm sewer in Minnesota (Goehring 1954), and a dry well in Massachusetts (Griffin 1945).

In December 2015, we recorded echolocation calls of M. septentrionalis (along with $E$. fuscus and $P$. subflavus) flying near rocky outcrops in eastern Nebraska (Lemen et al. 2016b). Acoustic evidence from that study suggests that bats were hibernating in rock crevices, but the possibility remained that they emerged from a different hibernaculum (e.g., a house) and were recorded as they flew by these rocky sites. In this study, we used a combination of acoustic detectors, thermal imaging cameras, and mist netting to confirm the use of a rock crevice by $M$. septentrionalis in winter in northeastern Nebraska.

To attempt to establish whether M. septentrionalis roosts in rock crevices in winter in
Nebraska, we returned to the 2 sites where we previously recorded bats flying near rock outcrops in winter: Little Blue Creek in Thayer County and Ponca State Park in Dixon County (Lemen et al. 2016b). Both sites have exposed rock in wooded areas near waterways that is composed of Greenhorn Limestone and Graneros Shale, and both have a variety of cracks that might offer potential roosts for bats. From January to March 2017, we set acoustic detectors (SM2Bat+ with SMX-U1 microphones and SM4BAT FS with SMM-U1 microphones, Wildlife Acoustics, https:/(www.wildlifeacoustics.com) at these 2 sites. The Little Blue Creek site has several vertical rocky outcrops that are about $2.5 \mathrm{~m}$ in height and variable in length and aspect, and we set at least one detector near each outcrop on several nights in January and February. Ponca State Park has a nearly continuous vertical rock face (about $10 \mathrm{~m}$ in height) that runs along the Missouri River. At this site, we initially set 6 detectors at about $20-\mathrm{m}$ intervals along a $100-\mathrm{m}$ section of the rocky cliffs that face northeast on 17 February 2017. We also set acoustic detectors on subsequent nights in February and March at this site. At both sites, microphones were attached to poles about $2-3 \mathrm{~m}$ in height and pointed at the rocks. We selected periods in winter with mild weather and let detectors record from sunset to sunrise.

Nebraska winters are generally cold the average high temperature in January at the Sioux City Airport, near the Ponca site, was $-1.7^{\circ} \mathrm{C}$, and the average low temperature was $\left.-12.2^{\circ} \mathrm{C}\right)$. However, occasional bouts of mild temperatures in winter are not uncommon in this region. For example, from 2010 to 2019 , the average number of days in January with temperatures of $0{ }^{\circ} \mathrm{C}$ or above was 6.3 (SD 2.7), and all years had at least 1 day in January above $0{ }^{\circ} \mathrm{C}$ (temperature data from Sioux City Airport, IA). During these periods of mild winter temperatures, M. septentrionalis is often active. Lemen et al. (2016a) found a $>50 \%$ likelihood of acoustical detection of M. septentrionalis outside a hibernaculum in eastern Nebraska in winter when sunset temperature was $0{ }^{\circ} \mathrm{C}$ or above. It should be noted that the levels of activity documented in Lemen et al. (2016a) were outside a mine positive for $P d$, and infected bats may have higher activity in winter. 
To identify species of bats recorded by acoustic detectors, we used Kaleidoscope Pro (Wildlife Acoustics), and then vetted all identifications manually. At the sites of detectors where we recorded the most bat passes of $M$. septentrionalis, we used thermal imaging cameras (IR Pad-640 Industrial Thermal Infrared Camera/Tablet System, ICI) on subsequent nights to record a video of a section of rocky outcrops about $25 \mathrm{~m}$ in length. At both the Little Blue and Ponca sites, we set 2 cameras out on each of 7 nights. Cameras typically recorded for about $3 \mathrm{~h}$, beginning at sunset. We also used acoustic detectors simultaneously when making videos. The clocks in the thermal imaging camera and the bat detector were synchronized so that the video recording of a bat could be associated with a sound file. The sound recordings could then be used to locate bat activity on video recordings, and also to identify the species of bat on video.

On 19 March 2017 at Ponca State Park, we stacked three $6-\mathrm{m}$ mist nets to cover the opening in the rock where bats were recorded emerging on previous nights. Nets were set up about $1.5 \mathrm{~h}$ before sunset and were taken down about $1.5 \mathrm{~h}$ after sunset. We recorded time of capture, sex, length of right forearm $(\mathrm{mm})$, and weight $(\mathrm{g})$ of each bat. We also examined bats for any visible signs of WNS and swabbed each bat on the wing and rostrum for $P d$. Swab samples were sent to the U.S. Geological Survey National Wildlife Health Center (Madison, WI) for analysis to detect $P d$. Our capture and handling of $M$. septentrionalis was approved by the Institutional Animal Care and Use Committee of the University of Nebraska Medical Center (IACUC 15-047-07-EP) and the USFWS (permit number TE79842A-1).

In January 2017, we recorded calls of $M$. septentrionalis at rocky outcrops along the Little Blue River, but, using thermal imaging cameras, we were unable to verify bats emerging from rock crevices. We viewed bats flying by rocky outcrops and landing on them, but we did not see bats emerging from a crevice. At Ponca State Park, we recorded calls of M. septentrionalis at several sites along a rock face bordering the Missouri River in February and March 2017, including one site near a large rock crevice. The distances from the large rock crevice and the number of bat passes recorded on 17 February (sunset temperature of $2{ }^{\circ} \mathrm{C}$ ) were as follows: $15 \mathrm{~m}$ from rock crevice, 41 passes; $22 \mathrm{~m}, 32$ passes; $28 \mathrm{~m}, 10$ passes; $40 \mathrm{~m}, 28$ passes; $42 \mathrm{~m}, 7$ passes; $66 \mathrm{~m}, 0$ passes. Thus, the closest detector to the rock crevice had the highest number of passes, and the most distant detector had no passes. On several subsequent nights, we recorded more bat passes of $M$. septentrionalis near the crevice and observed bats emerging from the crevice using thermal imaging cameras (supplemental material). We also observed a bat emerge from the crevice during daylight on 2 separate occasions. The opening of the crevice was about $4.3 \mathrm{~m}$ above the base of the cliff and measured $1.1 \mathrm{~m}$ in height and $0.3 \mathrm{~m}$ wide near the top of the crevice where it was widest (Fig. 1). Although we observed bats emerging from the crevice, results from the thermal camera indicated low activity during February, with only a few bats or no bats emerging from the crevice during $3 \mathrm{~h}$ of recording each night. To increase the chance of capturing bats to reaffirm the species using the crevice, we delayed netting until mid-March, when we assumed there would be higher activity.

On 19 March 2017, we captured 5 M. septentrionalis ( 3 females, 2 males) in mist nets covering the opening of the rock crevice (Fig. 1). Bats were captured from $48 \mathrm{~min}$ before sunset to $62 \mathrm{~min}$ after sunset. All bats were captured on the side of the net facing the opening. One bat escaped from the net, but it appeared to be on the outward-facing side of the net, so we were unsure whether this bat was returning and/or attempting to enter the rock crevice. We also saw 2 bats emerge from the opening while we were setting up the mist nets. These bats left the rock crevice $123 \mathrm{~min}$ and $113 \mathrm{~min}$ before sunset. Thus, the minimum number of bats in the rock crevice was 7 . The average body mass of bats was $5.4 \mathrm{~g}$ (masses ranged from 5 to $6 \mathrm{~g}$ ), and their wings were in good condition. None of the captured bats had any visible signs of WNS; however, all 5 bats tested positive for $P d$.

Our study is the first to confirm the use of a rock crevice in winter by $M$. septentrionalis. We suspected that northern long-eared myotis used rock crevices after we recorded their calls near rocky sites in December 2015 (Lemen et al. 2016b), and we verified them using one large limestone crevice along the Missouri River in northeastern Nebraska in 


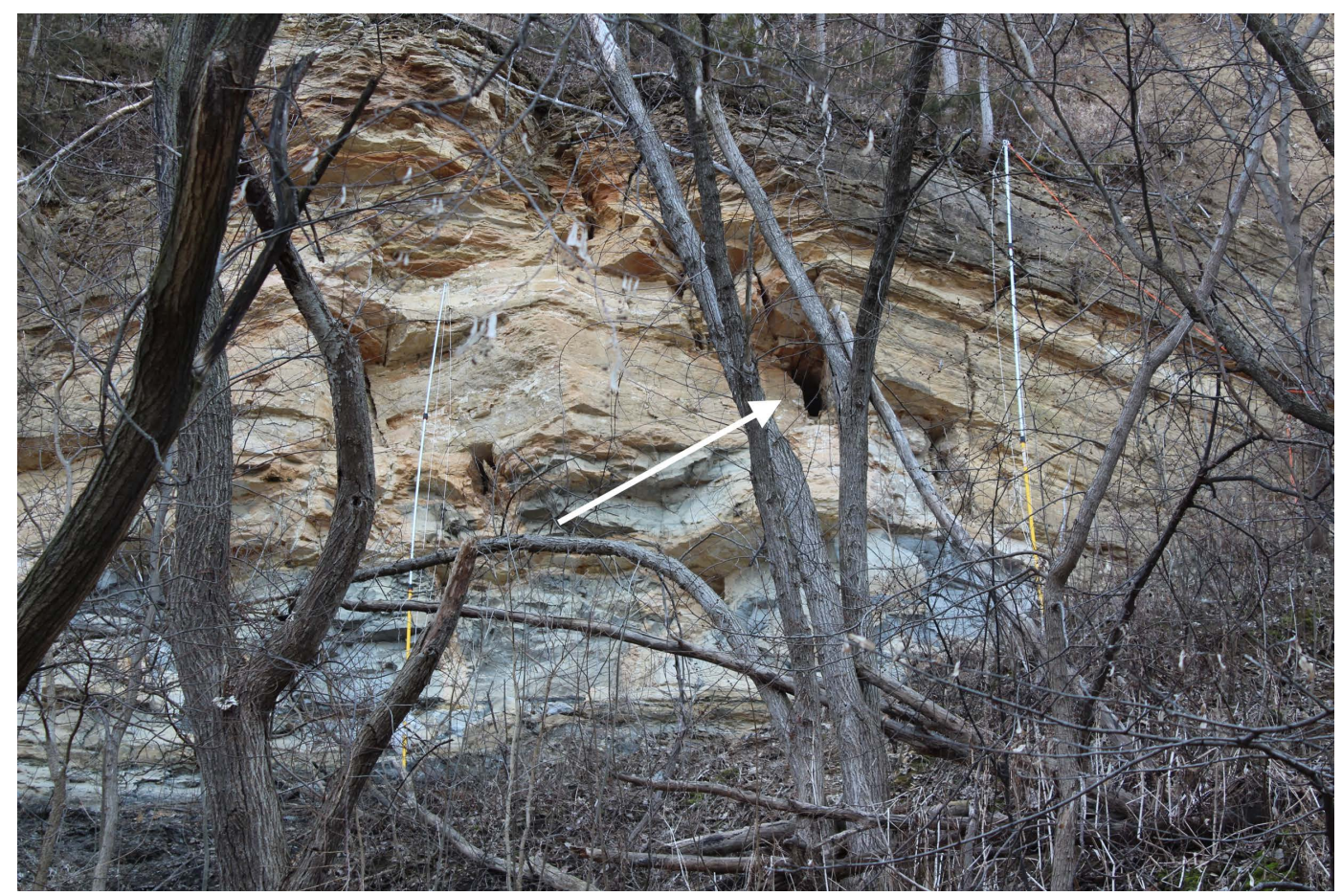

Fig. 1. The arrow shows the large crevice in the rock face that was used by northern long-eared myotis (Myotis septentrionalis) in winter 2016-2017. The rock face is near the edge of the Missouri River at Ponca State Park in northeastern Nebraska. A stacked net set with three 6-m mist nets (seen in the photo) was used to cover the opening to the crevice on 19 March 2017.

winter 2016-2017. The rock crevice used by M. septentrionalis was large compared to other cracks in the rock face at Ponca State Park (Fig. 1); in fact, at least one raccoon (Procyon lotor) was observed using the crevice at the same time as the bats. We suspect that M. septentrionalis also uses other crevices in the rock face, but more research will be necessary to understand the types of rock crevices used by this species.

We note that bats emerged from the crevice during daylight on 2 occasions. Daytime winter activity of bats near hibernacula has been observed previously in Tennessee, and daytime activity increased after $P d$ invaded hibernacula (Bernard and McCracken 2017). We do not know whether the bats we captured were more likely to be active during daytime because they were $P d$-positive or whether this is typical winter behavior for M. septentrionalis in this region. It is also possible that we disturbed the bats when we were setting up the mist nets, causing the bats to emerge from their hibernaculum during daylight, but it seems unlikely that setting up a camera well below the cliffs would have disturbed bats inside the crevice.

Different methods have been used to identify rock-crevice hibernacula of bats, including radiotelemetry (Lausen and Barclay 2006, Neubaum et al. 2006, Perry et al. 2010, Barnhart and Gillam 2017, Johnson et al. 2017, Klüg-Baerwald et al. 2017, Neubaum 2018) and visual inspection of crevices with flashlights (Moosman et al. 2017). Here we used a combination of acoustic detectors, thermal imaging cameras, and mist netting to confirm the use of a rock crevice by M. septentrionalis in winter. The convenience, reliability, and capacity of acoustic detectors to record for long periods of time make them a valuable tool in identifying potential hibernacula of bats. When confirmation of specific rock crevices is necessary, a variety of other techniques can be used. Thermal imaging cameras worked well in our study to record bats emerging from crevices in winter because bats were easily distinguished from the colder environment, and the use of both acoustic 
detectors and thermal cameras allowed us to identify species of bats on the video recordings. However, the thermal cameras we used were expensive, and in some cases they might not be necessary to identify rock-crevice hibernacula. If wintertime bat passes are recorded by acoustic detectors in an area with few crevices, then mist nets or harp traps could be used to cover the suspected openings to determine whether bats are using them without first using thermal cameras. We encourage bat researchers to modify our methods or experiment with different approaches to identify rock crevices used by bats in their regions.

The use of alternative hibernacula such as rock crevices is an important component of the natural history of temperate bats and warrants further research. Rock-crevice hibernacula have been difficult to discover previously, but bat biologists have recently identified a variety of species in different regions that use rock crevices in autumn and winter (Lausen and Barclay 2006, Neubaum et al. 2006, Perry et al. 2010, Barnhart and Gillam 2017, Johnson et al. 2017, Klüg-Baerwald et al. 2017, Moosman et al. 2017, Neubaum 2018). The identification of a rock-crevice hibernaculum used by M. septentrionalis in our study is an early step in understanding more about the winter roosting of this threatened species, and it provides evidence that $M$. septentrionalis is more flexible in its hibernation requirements than was previously thought. Continued research on alternative hibernacula could be critical for monitoring populations of this species as WNS, $P d$, or both continue to spread. This disease has decimated populations of M. septentrionalis in the eastern and midwestern United States (Langwig et al. 2012, 2015, 2016, Frick et al. 2015, 2017). To develop an effective recovery plan and practical monitoring strategies for $M$. septentrionalis, we need to understand more about the hibernation requirements of this species, including its potential reliance on rock-crevice hibernacula throughout its range.

\section{Supplementary Material}

One online-only supplementary file accompanies this article (https://scholarsarchive.byu .edu/wnan/vol80/iss1/14).

Supplementary Material 1. Thermal video of bat emerging from rock crevice.

\section{ACKNOWLEDGMENTS}

We thank the staff at Ponca State Park for allowing us to conduct research at this site. We also thank Trevor Harlow for assistance in the field and the U.S. Geological Survey National Wildlife Health Center for testing samples for $P d$. Many thanks to the Nebraska Game and Parks Commission and the U.S. Fish and Wildlife Service for funding this research.

\section{Literature Cited}

Barnhart, P.R., AND E.H. GILlaM. 2017. Documentation of overwintering bat species presence and hibernacula use in the badlands of North Dakota. Northwestern Naturalist 98:48-56.

Bernard, R.F., AND G.F. MCCRACKen. 2017. Winter behavior of bats and the progression of white-nose syndrome in the southeastern United States. Ecology and Evolution 7:1487-1496.

Bogan, M.A., P.M. Cryan, E.W. Valdez, L.E. Ellison, AND T.J. O’SHEA. 2003. Western crevice and cavityroosting bats. Pages 69-77 in T.J. O’Shea and M.A. Bogan, editors, Monitoring trends in bat populations of the United States and territories: problems and prospects. U.S. Geological Survey, Biological Resources Discipline, Information and Technology Report. 274 pp

Caceres, M.C., AND R.M.R. Barclay. 2000. Myotis septentrionalis. Mammalian Species 634:1-4.

Caire, W., R.K. LaVal, M.L. LaVal, and R. Clawson. 1979. Notes on the ecology of Myotis keenii (Chiroptera, Vespertilionidae) in eastern Missouri. American Midland Naturalist 102:404-407.

Frick, W.F., T.L. Cheng, K.E. Langwig, J.R. Hoyt, A.F. Janicki, K.L. Parise, J.T. Foster, and A.M. KilPATRICK. 2017. Pathogen dynamics during invasion and establishment of white-nose syndrome explains mechanisms of host persistence. Ecology 98:624-631.

Frick, W.F., S.J. Puechmaille, J.R. HoYt, B.A. Nickel, K.E. LangWig, J.T. Foster, K.E. Barlow, T. BARTONIČKA, D. Feller, A. Haarsma, et al. 2015. Disease alters macroecological patterns of North American bats. Global Ecology and Biogregraphy 24:741-749.

Goenring, H.H. 1954. Pipistrellus subflavus obscurus, Myotis keenii, and Eptesicus fuscus fuscus hibernating in a storm sewer in central Minnesota. Journal of Mammalogy 35:434-436.

Griffin, D.R. 1940. Notes on the life-histories of New England cave bats. Journal of Mammalogy 21:181-187.

Griffin, D.R. 1945. Travels of banded cave bats. Journal of Mammalogy 26:15-23.

Johnson, J.S., J.J. Treanor, M.J. Lacki, M.D. Baker, G.A. FalXa, L.E. Dodd, A.G. WaAG, and E.H. LEE. 2017. Migratory and winter activity of bats in Yellowstone National Park. Journal of Mammalogy 98: 211-221.

Klüg-Baerwald, B.J., C.L. Lausen, C.K.R. Willis, and R.M. BRIGHAM. 2017. Home is where you hang your bat: winter roost selection by prairie-living big brown bats. Journal of Mammalogy 98:752-760.

Kurta, A., And J.A. Teramino. 1994. A novel hibernaculum and noteworthy records of the Indiana bat and 
eastern pipistrelle (Chiroptera: Vespertilionidae). American Midland Naturalist 132:410-413.

Langwig, K.E., W.F. Frick, J.T. Bried, A.C. Hicks, T.H. KunZ, and A.M. Kilpatrick. 2012. Sociality, density-dependence and microclimates determine the persistence of populations suffering from a novel fungal disease, white-nose syndrome. Ecology Letters 15:1050-1057.

Langwig, K.E., W.F. Frick, J.R. Hoyt, K.L. Praise, K.P. Drees, T.H. Kunz, J.T. Foster, and A.M. KiLPATRICK. 2016. Drivers of variation in species impacts for a multi-host fungal disease of bats. Philosophical Transactions of the Royal Society B 371:1709. 9 pp.

Langwig, K.E., J.R. Hoyt, K.L. Parise, J. Kath, D. KirK, W.F. Frick, J.T. Foster, and A.M. Kilpatrick. 2015. Invasion dynamics of white-nose syndrome fungus, Midwestern United States, 2012-2014. Emerging Infectious Diseases 21:1023-1026.

Lausen, C.L., and R.M.R. Barclay. 2006. Winter bat activity in the Canadian prairies. Canadian Journal of Zoology 84:1079-1086.

Lemen, C.A., P.W. Freeman, and J.A. White. 2016a. Winter activity of Myotis septentrionalis: Role of temperature in controlling emergence from a hibernaculum. Transactions of the Nebraska Academy of Sciences 36:6-8.

Lemen, C.A., P.W. Freeman, and J.A. White. 2016b. Acoustic evidence of bats using rock crevices in winter: a call for more research on winter roosts in North
America. Transactions of the Nebraska Academy of Sciences 36:9-13.

Moosman, P.R., Jr., P.R. Anderson, and M.G. Frasier. 2017. Use of rock-crevices in winter by big brown bats and eastern small-footed bats in the Appalachian Ridge and Valley of Virginia. Banisteria 48:9-13.

Neubaum, D.J. 2018. Unsuspected retreats: autumn transitional roosts and presumed winter hibernacula of little brown myotis in Colorado. Journal of Mammalogy 99:1294-1306.

Neubaum, D.J., T.J. O’Shea, and K.R. Wilson. 2006. Autumn migration and selection of rock crevices as hibernacula by big brown bats in Colorado. Journal of Mammalogy 87:470-479.

Perry, R.W., D.A. Saugey, and B.G. Crump. 2010. Winter roosting ecology of silver-haired bats in an Arkansas forest. Southeastern Naturalist 9:563-572.

Twente, J.W. 1960. Environmental problems involving the hibernation of bats in Utah. Proceedings of the Utah Academy of Sciences, Arts and Letters 37:67-71.

WhitaKer, J.O., AND L.J. RissLer. 1992. Winter activity of bats at a mine entrance in Vermillion County, Indiana. American Midland Naturalist 127:52-59.

Received 14 November 2018 Revised 10 July 2019

Accepted 1 August 2019

Published online 7 February 2020 